\title{
Kecerdasan Spiritual dan Kecerdasan Emosional terhadap Organizational Citizenship Behavior (OCB) pada Aparatur Sipil Negara
}

\author{
Malahayati, Asmaran AS, dan Shanty Komalasari \\ Universitas Islam Negeri Antasari Banjarmasin
}

\begin{abstract}
Organizational Citizenship Behavior (OCB) is the behavior of the extra outside the description the work in the organization or agency carried out by the individual. OCB is the voluntary behaviors that are not listed in the description of the work and not known directly in the formal award system but it gives a positive impact for agency. OCB is able to give a sense of comfort in the environment agency as well as contribute indirectly toward the effectiveness of agency. Therefore, the researcher wants to conduct the research about the influence of spiritual intelligence and emotional intelligence to Organizational Citizenship Behavior (OCB) at state civil apparatus at the Ministry of Religion Banjarmasin. In this study, researcher used quantitative-field research method. Population in this research 69 state civil apparatus at the Ministry of Religion Banjarmasin. Based on research that was conducted at the Ministry of Religion Banjarmasin. The results of this study showed: 1) There are significant influence between the influence of spiritual intelligence and emotional artifice to Organizational Citizenship Behavior (OCB) at state civil apparatus at the Ministry of Religion Banjarmasin with significant level 0,006 $(p<0,05)$ and giving the effective impact $17,1 \%$. 2) There are significant influence between the influence of spiritual intelligence and emotional artifice to Organizational Citizenship Behavior (OCB) at state civil apparatus at the Ministry of Religion Banjarmasin with significant level,005 $(p<0,05)$ and giving the effective impact $13,1 \%$. 3) There are significant influence between the influence of spiritual intelligence and emotional artifice to Organizational Citizenship Behavior (OCB) at state civil apparatus at the Ministry of Religion Banjarmasin with significant level $0,011(p<0,05)$ and giving the effective impact $11,1 \%$.
\end{abstract}

Keywords: spiritual intelligence; emotional intelligence; Organizational Citizenship Behavior (OCB); The Ministry of Religion Banjarmasin.

\begin{abstract}
Abstrak
Organizational Citizenship Behavior (OCB) adalah perilaku tambahan di luar deskripsi pekerjaan dalam organisasi atau instansi yang dilakukan oleh individu. OCB merupakan perilaku sukarela yang tidak tercantum dalam deskripsi pekerjaan dan tidak dikenal secara langsung atau jelas dalam sistem penghargaan formal namun memberikan dampak positif bagi instansi. Perilaku OCB mampu memberikan rasa nyaman di lingkungan instansi serta berkontribusi secara tidak langsung terhadap efektivitas suatu instansi. Maka dari itu, peneliti hendak melakukan penelitian mengenai pengaruh kecerdasan spiritual dan kecerdasan emosional terhadap Organizational Citizenship Behavior (OCB) pada aparatur sipil negara di lingkungan Kantor Kementerian Agama Kota Banjarmasin. Penelitian ini merupakan penelitian lapangan (field research) dengan pendekatan kuantitiatif. Populasi dalam penelitian ini adalah aparatur sipil negara Kantor Kementerian Agama Kota Banjarmasin yang berjumlah 69 orang. Berdasarkan penelitian ini, maka didapatkan hasil: 1) Terdapat pengaruh yang signifikan antara kecerdasan spiritual dan kecerdasan
\end{abstract}


emosional terhadap OCB pada aparatur sipil negara di lingkungan Kantor Kementerian Agama Kota Banjarmasin dengan taraf signifikansi 0,006 ( $<<0,05)$ dan secara bersama-sama memberi sumbangan efektif sebesar 17,1\%. 2) Terdapat pengaruh yang siginifikan antara kecerdasan spiritual terhadap OCB pada aparatur sipil negara di lingkungan Kantor Kementerian Agama Kota Banjarmasin dengan taraf signifikansi 0,005 ( $\mathrm{p}<0,05)$ dan memberi sumbangan efektif sebesar $13,1 \% .3)$ Terdapat pengaruh yang siginifikan antara kecerdasan emosional terhadap OCB pada aparatur sipil negara di lingkungan Kantor Kementerian Agama Kota Banjarmasin dengan taraf signifikansi 0,011 $(p<0,05)$ dengan memberi sumbangan efektif sebesar $11,1 \%$.

Kata Kunci: kecerdasan emosional; kecerdasan spiritual; Kementerian Agama Kota Banjarmasin; Organizational Citizenship Behavior (OCB).

Kinerja individu dalam suatu organisasi dapat mempengaruhi kinerja tim dan akan memberikan dampak pada kinerja dan produktivitas organisasi atau instansi secara keseluruhan. Hal ini menyebabkan organisasi percaya bahwa untuk mencapai keunggulan yang kompetitif maka harus mengusahakan kinerja individu itu sendiri secara maksimal (Nur Izzah Maulidina, 2017). Dalam suatu organisasi perusahaan maupun instansi individu memiliki peranan yang sangat penting, yaitu sebagai tenaga yang menjalankan setiap aktivitas yang ada. Individu yang bekerja dalam suatu organisasi biasanya disebut sebagai karyawan atau Aparatur Sipil Negara (ASN) untuk organisasi yang ada di instansi pemerintahan. Keberhasilan suatu organisasi dalam menjawab tantangan-tantangan yang ada tidak hanya ditentukan oleh perilaku karyawan yang mengerjakan tugas sesuai deskripsi pekerjaannya. Kartz menyatakan bahwa perilaku-perilaku kerja sama dan saling membantu yang tidak termasuk dalam tugas ataupun tanggung jawab dalam suatu jabatan sangat penting untuk berfungsinya suatu organisasi. Perilaku tambahan di luar tanggung jawab pekerjaan dalam organisasi sering juga disebut dengan perilaku kewarganegaraan dalam organisasi atau Organizational Citizenship Behavior (OCB) (Sumiyarsih dkk., 2012).

OCB adalah perilaku diskresi yang mempromosikan fungsi efektif organisasi. OCB merupakan perilaku individu yang tidak dikenal secara langsung atau jelas dalam sistem reward atau penghargaan formal serta perilaku sukarela yang tidak tercatat dalam tanggung jawab pekerjaan mereka yang dapat diamati 
dan memberi dampak positif pada organisasi (Merrysha Tanu, 2012). OCB adalah perilaku yang memberikan sumbangan pada pemeliharaan dan peningkatan sosial dan konteks psikologis yang mendukung kinerja tugas. Definisi ini jelas menunjukkan bahwa perilaku-perilaku ini tidak dituntut dari pekerjaan, tetapi dilakukan oleh karyawan untuk meningkatkan lingkungan di organisasi dan berkontribusi secara tidak langsung terhadap efektivitas organisasi (Hafidz dkk., 2012). OCB menekankan kerelaan dan kebaikan dalam bekerja tanpa mendapatkan reward, hal ini identik dengan nilai-nilai dalam Islam yaitu perilaku ikhlas. Ikhlas adalah beribadah dan bekerja semata-semata karena Allah bukan karena ingin mendapatkan pujian dari orang lain ataupun mendapat imbalan berupa materi, sebagaimana dalam Q.S. An-Nisa ayat 125 (al- Qarni, 2008).

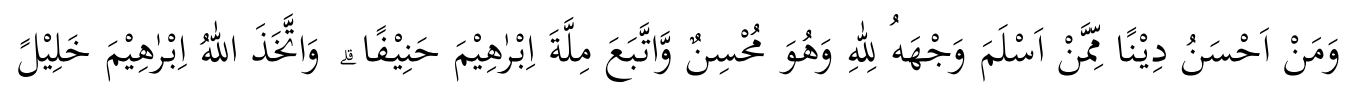

"Dan siapakah yang lebih baik agamanya dari pada orang yang ikhlas menyerahkan dirinya kepada Allah, sedang diapun mengerjakan kebaikan, dan ia mengikuti agama Ibrahim yang lurus? dan Allah mengambil Ibrahim menjadi kesayanganNya".

Perilaku OCB diperlukan di mana saja, bukan hanya pada perusahaan besar. Perilaku OCB ini juga sangat diperlukan pada instansi-instansi pemerintahan seperti kantor Kementerian Agama Kota Banjarmasin. Agar tercapainya tujuan organisasi maka setiap karyawan atau ASN di lingkungan kantor Kemeterian Agama Kota Banjarmasin diharapkan memiliki sikap profesional, teratur, kontinyuitas, dedikasi, kerja keras dan kejujuran dalam bekerja. Selain itu ASN juga diharapkan mampu memiliki sikap sukarela dalam membantu sesama rekan kerja dan disiplin dalam menaati peraturan sebagai pendukung agar terciptanya lingkungan kerja yang nyaman. Namun yang terjadi di lapangan tidak semua ASN di lingkungan kantor Kementerian Agama Kota Banjarmasin memiliki perilaku OCB, masih ada ASN yang kurang disiplin dalam menaati peraturan, hanya mengerjakan tugas formal yang sudah ditetapkan organisasi dan mengenyampingkan perilaku OCB. Seperti yang ditemukan saat observasi selama peneliti melakukan proses praktik kerja psikologi di Kementerian Agama Kota Banjarmasin. 
Hal tersebut juga didukung dengan hasil wawancara dengan salah satu ASN di lingkungan kantor Kementerian Agama Kota Banjarmasin yang menyatakan bahwa setiap orang sudah memiliki pekerjaannya masing-masing dan sudah dibagi dengan jelas oleh ketua seksi (KASI), maka setiap orang memiliki kewajiban untuk mengerjakan tugasnya. Namun selain tugas yang diberikan oleh atasan, diberikan kebebasan untuk mengerjakan hal lain, misalnya menggantikan pekerjaan dari ASN yang sedang berhalangan hadir, memberikan bantuan pada rekan kerja yang sedang banyak pekerjaan, dan lain sebagainya.

Perilaku OCB tidak lepas dari bagaimana individu itu memaknai pekerjaannya dengan memahami lingkungan sekitar serta bertindak sesuai dengan tujuan bersama. Kemampuan untuk bertanggungjawab terhadap diri sendiri dan mengatur diri sendiri erat kaitannya dengan bagaimana seseorang memaknai dan menilai setiap tindakannya. Kemampuan untuk menilai makna hidup dan makna tindakan serta kemampuan memahami orang lain erat kaitannya dengan dua kecerdasan yang dimiliki manusia itu sendiri yaitu kecerdasan spiritual dan kecerdasan emosional (Husain, 2013).

Kecerdasan spiritual dalam Kamus Besar Bahasa Indonesia (KBBI) adalah kecerdasan yang berkaitan dengan hati dan kepedulian antar sesama manusia, makhluk lain, dan alam sekitar berdasarkan keyakinan akan adanya Tuhan Yang Maha Esa(Departemen Pendidikan Nasional, 2013). Menurut Zohar dan Marshal kecerdasan spiritual merupakan suatu konsep yang berhubungan dengan bagaimana seseorang cerdas dalam mengatur dan menggunakan nilai, makna dan kualitas kehidupan spiritual (Mujib \& Mudzakir, 2002). Sedangkan Tasmara menyatakan kecerdasan spiritual adalah kemampuan individu dalam menempatkan diri dalam pergaulan, kemampuan untuk mendengarkan hati nuraninya, membedakan hal yang baik dan yang tidak baik (Toto Tasmara, 2003).

Kecerdasan emosional adalah suatu kecerdasan yang merujuk pada kemampuan dalam mengenali perasaan diri kita sendiri dan perasaan orang lain, kemampuan memotivasi diri sendiri serta kemampuan dalam mengatur emosi dengan baik pada diri sendiri maupun dalam hubungan dengan orang lain. 
Kecerdasan emosional juga diartikan sebagai kemampuan pribadi, emosi, dan sosial yang mempengaruhi kemampuan seseorang untuk berhasil dalam mengatasi tuntutan dan tekanan lingkungan (Masruroh, 2014). Berdasarkan latar belakang tersebut peneliti ingin mengetauhi apakah ada pengaruh kecerdasan spiritual dan kecerdasan emosional terhadap Organizational Sitizenship Behavior (OCB) pada aparatur sipil negara di lingkungan kantor Kementerian Agama Kota Banjarmasin.

\section{Metode}

Metode penelitian yang digunakan adalah penelitian kuantitatif dengan jenis penelitian lapangan atau field research. Subjek pada penelitian ini adalah ASN yang bekerja di kantor Kementerian Agama Kota Banjarmasin yaitu 69 orang. Teknik dalam pengambilan sampel pada penelitian ini adalah teknik probability sampling yang artinya setiap unsur (anggota) populasi diberikan peluang yang sama untuk menjadi sampel (Sugiyono, 2010). Sampel dalam penelitian ini yaitu 58 subjek dengan tingkat kepercayaan 95\% berdasarkan tabel Isaac dan Michael (Mulyatiningsih, 2011). Objek pada penelitian ini yaitu kecerdasan spiritual dan kecerdasan emosional sebagai variabel bebas serta OCB sebagai variabel terikat.

Pengumpulan data dalam penelitian ini menggunakan 3 skala psikologi yaitu skala kecerdasan spiritual, skala kecerdasan emosional, dan skala OCB. Skala kecerdasan spiritual disusun berdasarkan aspek yang dikemukakan oleh Tasmara yaitu memiliki tujuan hidup yang jelas, memiliki prinsip hidup, cederung pada kebaikan, dan berjiwa besar (Toto Tasmara, 2003). Skala kecerdasan emosional dalam penelitian ini menggunakan skala yang disusun oleh Astuti yang sudah terbukti validitas dan reliabilitasnya dengan nilai signifikansi 0,852 (Ayu Widya Astuti, 2018). Dan skala OCB pada penelitian ini menggunakan skala OCB yang diadaptasi dari William dan Anderson dengan peer review di Indonesia yang disusun oleh Novika Grasiaswaty, dkk. Hasil dari adaptasi alat ukur OCB ini terbukti valid dan reliabel untuk mengukur konstruk OCB pada karyawan di Indonesia dengan nilai signifikasi 0,845 (Grasiaswaty dkk., 2014). Selain itu pada penelitian ini juga menggunakan dokumentasi, wawancara, dan observasi sebagai 
data pendukung.

Analisis data pada penelitian ini menggunakan teknik analisis regresi berganda. Analisis regresi berganda dilakukan untuk penelitian yang memiliki satu variabel terikat dan lebih dari satu variabel bebas (Sujarweni, 2019). Sebelum melakukan uji analisis maka dilakukan uji asumsi dasar yaitu uji normalitas dan uji linieritas serta uji asumsi klasik yaitu uji multikolinieritas dan uji heterokedastisitas. Proses analisis dibantu dengan menggunakan program komputer Statictical Packages for Social Sciense (SPSS) Release 20.0for windows.

\section{H a s i 1}

\section{Uji Asumsi Dasar}

Hasil uji normalitas pada variabel kecerdasan spiritual, kecerdasan emosional, dan OCB menunjukkan nilai signifikansi kolmogrov-smirnov sebesar 0,200 ( $\mathrm{p}>0,05)$. Hal ini menunjukkan bahwa data kecerdasan spiritual, kecerdasan emosional, dan OCB dalam penelitian ini memiliki data yang berdistribusi normal. Hasil uji linieritas untuk variabel kecerdasan spiritual terhadap OCB menunjukkan nilai signifikansi 0,001 ( $\mathrm{p}<0,05)$. Hal ini menunjukkan bahwa perubahan variabel bebas kecerdasan spiritual akan cenderung diikuti oleh perubahan variabel terikat OCB. Sedangkan uji linieritas untuk variabel kecerdasan spiritual terhadap OCB 0,007 ( $\mathrm{p}<0,05)$. Hal ini menunjukkan bahwa perubahan variabel bebas kecerdasan emosional akan cenderung diikuti oleh perubahan variabel terikat OCB.

Uji Asumsi Klasik

Hasil uji multikolinieritas pada kedua variabel bebas yaitu kecerdasan spiritual dan kecerdasan emosional memiliki VIF dari hasil uji multikolinieritas masih diantara 1-10 yaitu sebesar VIF=1,202. Artinya antara variabel bebas tidak terjadi multikolinieritas atau kemiripan, sehingga memenuhi syarat untuk dianalisis regresi. Sehingga tidak bias dalam proses pengambilan keputusan mengenai pengaruh pada uji parsial masing-masing variabel bebas terhadap variabel terikat. Selanjutnya hasil uji heterokedastisitas pada kedua variabel bebas yaitu kecerdasan spiritual dan kecerdasan emosional memiliki nilai signifikansi 1,000 ( $\mathrm{p}>0,05)$. Artinya tidak ada ketidaksamaan varian dari residul (selisih antara 
nilai duga dengan nilai pengamatan sebenarnya) suatu pengamatan ke pengamatan lain antara variabel bebas kecerdasan spiritual dan kecerdasan emosional.

Uji Hipotesis

Hasil analisis regresi berganda menunjukkan nilai signifikansi 0,006 ( $\mathrm{p}<$ 0,05), artinya dapat disimpulkan bahwa ada pengaruh kecerdasan spiritual dan kecerdasan emosional terhadap OCB pada ASN di lingkungan kantor Kementerian Agama Kota Banjarmasin. Untuk lebih jelasnya berikut ini adalah table hasil analisis regresi berganda:

Tabel 1

\begin{tabular}{ccccc}
\hline Model & $R$ & $R$ Square & Adjusted R Square & Std. Error of the Estimate \\
\hline 1 &, $414^{\mathrm{a}}$ &, 171 &, 141 & 3,630 \\
\hline
\end{tabular}

Dari tabel 1 di atas diketahui bahwa nilai koefisien determinan ( $R$ square) sebesar 0,171. Hal tersebut menunjukkan bahwa variabel bebas kecerdasan spiritual dan kecerdasan emosional secara bersama-sama memberi sumbangan efektif terhadap variabel terikat OCB sebesar $17,1 \%$.

Pada penelitian ini juga dilakukan analisis regresi sederhana untuk mengetahui bagian-bagian dari analisis berganda. Hasil analisis regresi sederhana untuk pengaruh variabel kecerdasan spiritual terhadap OCB menunjukkan nilai signifikansi sebesar 0,005 ( $\mathrm{p}<0,05)$, artinya ada pengaruh kecerdasan spiritual terhadap OCB pada ASN di lingkungan kantor Kementerian Agama Kota Banjarmasin. Untuk lebih jelasnya berikut ini adalah tabel hasil analisis regresi sederhana kecerdasan spiritual terhadap OCB:

Tabel 2

\begin{tabular}{ccccc}
\hline Model & $R$ & $R$ Square & Adjusted $R$ Square & Std. Error of the Estimate \\
\hline 1 &, $361^{\mathrm{a}}$ &, 131 &, 115 & 3,685 \\
\hline
\end{tabular}


Dari tabel 2 di atas diketahui bahwa nilai koefisien determinan ( $R$ square) sebesar 0,131. Hal tersebut menunjukkan bahwa variabel bebas kecerdasan spiritual memberi sumbangan efektif terhadap variabel terikat OCB sebesar 13,1\%.

Selanjutnya hasil analisis regresi sederhana untuk pengaruh variabel kecerdasan emosional terhadap OCB menunjukkan nilai signifikansi sebesar 0,011 $(\mathrm{p}<0,05)$, artinya ada pengaruh kecerdasan emosional terhadap OCB pada ASN di lingkungan kantor Kementerian Agama Kota Banjarmasin. Untuk lebih jelasnya berikut ini adalah tabel hasil analisis regresi sederhana kecerdasan emosional terhadap OCB:

Tabel 3

\begin{tabular}{ccccc}
\hline Model & $R$ & $R$ Square & Adjusted $R$ Square & Std. Error of the Estimate \\
\hline 1 &, $333^{\mathrm{a}}$ &, 111 &, 095 & 3,727 \\
\hline
\end{tabular}

Dari tabel 3 di atas diketahui bahwa nilai koefisien determinan ( $R$ square) sebesar 0,111. Hal tersebut menunjukkan bahwa variabel bebas kecerdasan emosional memberi sumbangan efektif terhadap variabel terikat OCB sebesar $11,1 \%$.

Penelitian ini juga membuat kategorisasi untuk setiap variabel, hal ini bertujuan untuk menempatkan individu atau subjek penelitian ke dalam kelompok-kelompok yang posisi berjenjang menurut suatu kontinum berdasarkan atribut yang diukur (Azwar, 2013). Berikut adalah data tabel yang akan menjabarkan tentang tingkat kecerdasan spiritual, kecerdasan emosional, dan OCB pada ASN di lingkungan kantor Kementerian Agama Kota Banjarmasin.

Tabel 4

Tingkat Kecerdasan Spiritual ASN

\begin{tabular}{cccc}
\hline Kategori & Norma & Frekuensi & Persentase \\
\hline$X>57,73$ & Tinggi & 8 & $13,8 \%$ \\
\hline $49,64 \leq X<57,73$ & Sedang & 42 & $72,4 \%$ \\
\hline
\end{tabular}




\begin{tabular}{llll}
\hline$X<49,65$ & Rendah & 8 & $13,8 \%$ \\
\hline
\end{tabular}

Berdasarkan tabel 4 di atas dapat diketahui bahwa tingkat kecerdasan spiritual ASN di lingkungan kantor Kementerian Agama Kota Banjarmasin dengan kategori tinggi sebesar $13,8 \%$ ( 8 orang), kategori sedang $72,4 \%$ (42 orang), dan pada kategori rendah $13,8 \%$ (8 orang).

Tabel 5

Tingkat Kecerdasan Emosional

\begin{tabular}{cccc}
\hline Kategori & Norma & Frekuensi & Persentase \\
\hline$X>49,833$ & Tinggi & 7 & $12,1 \%$ \\
\hline $40,727 \leq X<49,833$ & Sedang & 46 & $79,3 \%$ \\
\hline$X<40,427$ & Rendah & 5 & $8,6 \%$ \\
\hline
\end{tabular}

Berdasarkan tabel 5 di atas dapat diketahui bahwa tingkat kecerdasan emosional ASN di lingkungan kantor Kementerian Agama Kota Banjarmasin dengan kategori tinggi sebesar $12,1 \%$ (7 orang), kategori sedang 79,3\% (46 orang), dan pada kategori rendah 8,6\% (5 orang).

Tabel 6

Tingkat Organnizational Citizenship Behavior (OCB)

\begin{tabular}{cccc}
\hline Kategori & Norma & Frekuensi & Persentase \\
\hline$X>36,417$ & Tinggi & 14 & $24,1 \%$ \\
\hline $28,583 \leq X<36,417$ & Sedang & 41 & $70,7 \%$ \\
\hline$X<28,538$ & Rendah & 3 & $5,2 \%$ \\
\hline
\end{tabular}

Berdasarkan tabel 6 di atas dapat diketahui bahwa tingkat OCB pada ASN di lingkungan kantor Kementerian Agama Kota Banjarmasin dengan kategori tinggi sebesar $24,1 \%$ (14 orang), kategori sedang 70,7\% (41 orang), dan pada kategori rendah $5,2 \%$ (3 orang). 


\section{Pembahasan}

Organ mendefinisikan Organizational Citizenship Behavior (OCB) sebagai suatu perilaku diskresi atau perilaku bebas yang dimiliki individu untuk mengambil keputusan dalam setiap situasi yang mempromosikan fungsi efektif organisasi. OCB merupakan perilaku individu tidak dikenal secara langsung atau jelas dalam sistem penghargaan formal, serta perilaku sukarela yang tidak tercatat dalam deskripsi pekerjaan mereka yang dapat diamati dan memberi dampak positif pada organisasi (Merrysha Tanu, 2012). Lebih lanjut, Organ juga mendefinisikan OCB sebagai perilaku yang berkontribusi pada pemeliharaan dan peningkatan sosial dan konteks psikologis yang mendukung kinerja tugas (Hafidz dkk., 2012). Jadi, OCB merupakan perilaku-perilaku yang tidak dituntut dari pekerjaan, tetapi dilakukan oleh karyawan untuk meningkatkan lingkungan di organisasi, dan berkontribusi secara tidak langsung terhadap efektivitas organisasi. Gambaran OCB ditinjau melalui aspek yang dikemukakan oleh Organ yaitu altruisme, courtesy, sportmanship, civic virtue, dan conscientiousness.

Faktor yang memiliki pengaruh terhadap OCB di antaranya adalah kecerdasan spiritual dan kecerdasan emosional. Kecerdasan spiritual menurut Tasmara merupakan kemampuan seseorang untuk mendengarkan hati nuraninya, baik-buruk, dan rasa moral dalam menempatkan diri dalam pergaulan (Toto Tasmara, 2003). Sedangkan kecerdasan emosional menurut Salovey dan Mayer merupakan himpunan bagian dari kecerdasan sosial yaitu kemampuan memantau perasaan sosial yang melibatkan kemampuan pada orang lain, memilah-milah semuanya, dan menggunakan informasi ini untuk membimbing pikiran dan tindakan (Lubis, 2018).

Gambaran kecerdasan spiritual ditinjau melalui aspek-aspek yang dikemukakan oleh Tasmara. Aspek-aspek itu dimuat dalam skala sesuai dengan teori yang sudah dijelaskan oleh peneliti dalam definisi operasional dan landasan teori di mana aspek-aspek tersebut berkaitan dengan perilaku yang menggambarkan kecerdasan spiritual seseorang seperti memiliki tujuan hidup yang jelas, memiliki prinsip hidup, cenderung kepada 
kebaikan, dan berjiwa besar. Sedangkan gambaran kecerdasan emosional ditinjau melalui aspek-aspek yang dikemukakan oleh Salovey. Di mana aspek-aspek itu berkaitan dengan perilaku yang menggambarkan kecerdasan emosional seseorang seperti mengenali emosi diri, mengelola emosi, memotivasi diri, mengenali emosi orang lain, dan membina hubungan.

Pada penelitian ini, peneliti mengajukan tiga hipotesis kerja (Ha) dan ketiga hipotesis kerja tersebut dapat diterima. Berdasarkan hasil uji hipotesis pertama dan untuk menjawab rumusan masalah kesatu, diketahui dengan jelas bahwa terdapat pengaruh yang signifikan antara kecerdasan spiritual dan kecerdasan emosional terhadap OCB pada ASN di lingkungan kantor Kementerian Agama Kota Banjarmasin, dengan sumbangan efektif yang diberikan sebesar $17,1 \%$ sedangkan $82,9 \%$ dipengaruhi oleh faktor lain yang tidak termasuk dalam penelitian ini.

Berdasarkan hasil uji hipotesis kedua dan untuk menjawab rumusan masalah tersebut, diperoleh pengaruh yang signifikan antara kecerdasan spiritual terhadap OCB pada ASN di lingkungan kantor Kementerian Agama Kota Banjarmasin, memiliki sumbangan efektif $13,1 \%$. Kemudian berdasarkan hasil uji hipotesis ketiga dan untuk menjawab rumusan masalah ini, diperoleh hasil bahwa terdapat pengaruh yang signifikan antara kecerdasan emosional terhadap OCB pada ASN di lingkungan kantor Kementerian Agama Kota Banjarmasin, dengan memberikan pengaruhnya sebesar 11,1\%.

Sesuai dengan hasil analisis, maka dapat diambil kesimpulan bahwa terdapat pengaruh yang signifikan antara kecerdasan spiritual dan kecerdasan emosional terhadap OCB pada ASN di lingkungan kantor Kementerian Agama Kota Banjarmasin. Hal ini menyatakan bahwa OCB seseorang tidak mutlak dipengaruhi oleh kecerdasan spiritual dan kecerdasan emosional yang dimiliki oleh individu. Antara kecerdasan spiritual dan kecerdasan emosional memang dapat memberikan pengaruh terhadap OCB, akan tetapi bisa saja seseorang yang memiliki OCB yang tinggi dikarenakan faktor-faktor penyebab lain yang tidak diteliti pada penelitian ini. Seperti faktor internal di antaranya moral karyawan, 
komitmen organisasi, kepuasan kerja, kepribadian, dan motivasi. Serta faktor eksternal yaitu kepercayaan pada pimpinan, gaya kepemimpinan, dan budaya organisasi (Titisari, 2014). Hal ini juga dibuktikan dengan penelitian yang dilakukan oleh Rahmawati dan Prasetya dengan judul "Analisis Faktor-Faktor yang Mempengaruhi Organizational Citizenship Behavior (OCB) pada Karyawan Tetap dan Karyawan Kontrak (Studi pada Karyawan Pizza Hut Kota Malang)". Pada penelitian ini disebutkan faktor-faktor yang mempengaruhi OCB secara dominan yaitu kepercayaan pada pimpinan, motivasi, moral karyawan, kepribadian, gaya kepemimpinan, komitmen organisasi, kepuasan kerja, dan budaya organisasi (Rahmawati \& Prasetya, 2017).

Untuk menjawab rumusan masalah yang keempat tentang tingkat kecerdasan spiritual pada ASN di lingkungan kantor Kementerian Agama Kota Banjarmasin, diketahui dari hasil penelitian ini bahwa kecerdasan spiritual berada pada kategori tinggi sejumlah 8 orang $(13,8 \%)$, pada kategori sedang sejumlah 42 orang $(72,4 \%)$, dan pada kategori rendah sejumlah 8 orang $(13,8 \%)$. Secara umum kecerdasan spiritual ASN di lingkungan kantor Kementerian Agama Kota Banjarmasin berada pada kategori sedang. Kecerdasan spiritual pada tingkat sedang ini juga bisa dikatakan dalam keadaan baik. Pada dasarnya setiap kecerdasan spiritual seseorang itu berbeda, adapun faktor yang dapat mempengaruhi kecerdasan spiritual seseorang adalah drive yaitu dorongan dan usaha untuk mencapai kebenaran dan kebahagiaan. Selain itu juga bisa dipengaruhi oleh faktor inner value (nilainilai) spiritual dari dalam yang berasal dari dalam diri, suara hati, tanggung jawab, adil, dan kesadaran sosial (Tri Yuliani, 2018).

Kecerdasan spiritual yang baik akan memberikan dampak yang baik pula pada individunya. Menurut Zohar dan Marshall fungsi dari kecerdasan spiritual adalah kecerdasan untuk menempatkan perilaku dan hidup individu dalam konteks makna yang lebih luas dan kaya. Sehingga seseorang mampu menjadi kreatif, berwawasan luas, berani, optimis, dan fleksibel. Kecerdasan spiritual juga kecerdasan yang digunakan dalam masalah eksistensial, yaitu ketika seseorang secara pribadi merasa terpuruk, terjebak oleh 
kebiasaan, kekhawatiran, dan masalah masa lalu akibat penyakit dan kesedihan. Serta kecerdasan yang memberikan rasa moral, kemampuan menyesuaikan aturan kaku diiringi dengan pemahaman sampai batasnya. Kecerdasan spiritual menjadikan kita sadar bahwa kita memiliki masalah eksistensial dan membuat kita mampu mengatasinya. Kecerdasan ini juga berfungsi sebagai landasan bagi seseorang untuk memfungsikan IQ dan EQ secara efektif (Zohar \& Marshall, 2007).

Kecerdasan spiritual adalah kecerdasan yang menjadikan individu mampu mengetahui tentang siapa dirinya dan apa makna segala sesuatu baginya serta bagaimana semua itu memberikan suatu tempat di dalam dunia kepada orang lain dan makna-makna mereka. Kecerdasan spiritual memungkinkan individu untuk menyatukan hal-hal yang bersifat intrapersonal dan interpersonal, serta menjembatani kesenjangan antara diri dan orang lain. Kecerdasan spiritual juga dapat menjadikan individu lebih cerdas secara spiritual dalam beragama, sehingga seseorang memiliki kecenderungan spiritual tinggi tidak berpikiran eksklusif, fanatik, dan berprasangka (Zohar \& Marshall, 2007).

Pada penelitian ini kecerdasan spiritual berada pada tingkat sedang atau baik juga diimbangi dengan kecerdasan emosional yang umumnya pada tingkat sedang. Dari hasil penelitian ini diperoleh data bahwa kecerdasan emosional berada pada kategori tinggi sejumlah 7 orang (12,1\%), pada kategori sedang sejumlah 46 orang $(79,3 \%)$, dan pada kategori rendah sejumlah 5 orang $(8,6 \%)$. Individu yang memiliki tingkat kecerdasan emosional yang baik akan memberikan manfaat yang besar bagi kehidupan seseorang, seperti peningkatan kualitas hidup sehingga dapat merasakan kesuksesan dan kesejahteraan dalam hidup.

Kecerdasan emosional menjadikan seseorang mampu mengatasi stres, menghadapi tekanan stres, dan mampu menahan emosi sehingga tidak akan terlarut dalam stres. Kecerdasan emosional juga membuat seseorang mampu menahan diri misalnya mampu menunda kesenangan sesaat untuk mendapatkan hasil yang lebih baik. Seseorang yang memiliki kecerdasan emosional yang baik juga akan mampu mengelola suasana hati yaitu 
tetap tenang dalam suasana apa pun, mampu menghilangkan kecemasan yang timbul, mengatasi kesedihan, dan mampu mengatasi suasana yang menjengkelkan.

Seseorang yang memiliki kecerdasan emosional yang baik akan mampu memotivasi diri sendiri sehingga akan cenderung sangat produktif dan efektif dalam hal apa pun. Kecerdasan emosional juga membuat seseorang memiliki keterampilan sosial seperti mudah bergaul, menjadi pribadi yang menyenangkan, dan toleransi terhadap orang lain. Kecerdasan emosional menjadikan seseorang mampu memahami orang lain atau yang disebut sebagai empati (“Manfaat Kecerdasan Emosional (EQ)," 2020).

Selanjutnya untuk menjawab rumusan masalah yang terakhir atau yang keenam tentang tingkat OCB pada ASN di lingkungan kantor Kementerian Agama Kota Banjarmasin. Dari hasil penelitian ini diperoleh data bahwa OCB berada pada kategori tinggi sejumlah 14 orang (24,1\%), pada kategori sedang sejumlah 41 orang $(70,7 \%)$, dan pada kategori rendah sejumlah 3 orang (5,2\%). Jadi secara umum OCB pada ASN di lingkungan kantor Kementerian Agama Kota Banjarmasin adalah sedang. Kategori pada tingkatan sedang artinya bisa dikatakan telah dalam kondisi yang baik, tetapi akan lebih baik jika ditingkatkan lagi. Karena OCB memberikan manfaat yang positif bagi instansi, sebagaimana yang telah dijelaskan pada bab sebelumnya bahwa OCB mampu meningkatkan produktivitas rekan kerja, meningkatkan stabilitas kinerja organisasi meningkatkan produktivitas kepala organisasi, menghemat sumber daya yang dimiliki manajemen dan organisasi secara keseluruhan, menjadi sarana efektif untuk mengoordinasi kegiatan-kegiatan kelompok kerja, perilaku OCB akan membantu menghemat energi sumber daya yang langka untuk memelihara fungsi kelompok, mampu meningkatkan kemampuan organisasi untuk menarik dan mempertahankan karyawan terbaik, serta mampu meningkatkan kemampuan organisasi untuk beradaptasi dengan perubahan lingkungan (Diana, 2012). 


\section{Kesimpulan}

Dari hasil analisis data dalam penelitian mengenai pengaruh kecerdasan spiritual dan kecerdasan emosional terhadap Organizational Citizenship Behavior (OCB) pada Aparatur Sipil Negara (ASN) di lingkungan kantor Kementerian Agama Kota Banjarmasin, maka dapat disimpulkan bahwa ada pengaruh yang signifikan antara kecerdasan spiritual dan kecerdasan emosional terhadap OCB. Pengaruh yang diberikan sebesar 17,1\%. Selanjutnya ada pengaruh yang signifikan antara kecerdasan spiritual terhadap OCB pada penelitian ini, sebesar $13,1 \%$. Serta ada pengaruh yang signifikan antara kecerdasan emosional terhadap OCB, dengan persentase sebesar 11,1\%. Yang artinya kecerdasan spiritual dan kecerdasan emosional dapat mempengaruhi OCB pada ASN di lingkungan Kementerian Agama Kota Banjarmasin baik secara bersama-sama ataupun secara satu persatu.

Untuk hasil data kecerdasan spiritual pada ASN di lingkungan kantor Kementerian Agama Kota Banjarmasin, dikatakan bahwa pada kategori tinggi berjumlah 8 orang (13,8\%), pada kategori sedang berjumlah 42 orang $(72,4 \%)$, dan pada kategori rendah berjumlah 8 orang (13,8\%). Hal ini menunjukkan bahwa kecerdasan spiritual pada ASN di lingkungan kantor Kementerian Agama Kota Banjarmasin dominan berada pada kategori sedang. Untuk hasil data kecerdasan emosional pada ASN di lingkungan kantor Kementerian Agama Kota Banjarmasin, diketahui bahwa pada kategori tinggi berjumlah 7 orang $(12,1 \%)$, pada kategori sedang berjumlah 46 orang $(79,3 \%)$, dan pada kategori rendah berjumlah 3 orang $(8,6 \%)$. Hal ini menunjukkan bahwa kecerdasan emosional pada ASN di lingkungan kantor Kementerian Agama Kota Banjarmasin dominan berada pada kategori sedang. Serta untuk hasil data OCB pada ASN di lingkungan kantor Kementerian Agama Kota Banjarmasin pada kategori tinggi berjumlah 14 orang (24,1\%), pada kategori sedang berjumlah 41 orang $(70,7 \%)$, dan pada kategori rendah berjumlah 3 orang (5,2\%). Hal ini menunjukkan bahwa OCB pada ASN di lingkungan kantor Kementerian Agama Kota 
Banjarmasin dominan berada pada kategori sedang.

\section{Saran}

Penelitian ini menunjukkan adanya pengaruh kecerdasan spiritual dan kecerdasan emosional terhadap Organizational Citizenship Behavior (OCB) pada ASN di lingkungan Kementerian Agama Kota Banjarmasin. Untuk itu disarankan kepada kantor Kementerian Agama Kota Banjarmasin hendaknya berupaya meningkatkan perilaku OCB, tidak hanya melalui pengembangan kecerdasan spiritual dan kecerdasan emosional, namun juga memperhatikan faktor-faktor lain yang dapat meningkatkan OCB. Karena OCB akan memberikan dampak positif bagi instansi itu sendiri. Untuk peneliti selanjutnya yang menggunakan variabel yang sama disarankan agar menggunakan teori-teori yang berbeda untuk memperkaya pembahasan penelitian terkait variabel kecerdasan spiritual, kecerdasan emosional, dan OCB. Selain itu peneliti juga menyarankan untuk penelitian selanjutnya meneliti lebih mendalam mengenai variabel-variabel yang dapat mempengaruhi OCB, penelitian selanjutnya juga bisa mengubah metode penelitian ke penelitian kualitatif agar mendapatkan uraian data penelitian yang lebih mendalam mengenai faktor yang dapat mempengaruhi OCB.

\section{Referensi}

al-Qarni, 'Aidh. (2008). Tafsir Muyassar Jilid 1. Qisthi Press.

Ayu Widya Astuti. (2018). Pengaruh Kecerdasan Emosional Terhadap Etos Kerja Karyawan TVRI Kalimantan Selatan di Banjarmasin [Skripsi]. UIN Antasari Banjarmasin.

Azwar, S. (2013). Penyusunan Skala Psikologi. Pustaka Pelajar.

Departemen Pendidikan Nasional. (2013). Kamus Besar Bahasa Indonesia. PT Gramedia Pustaka Utama.

Diana, I. N. (2012). Organizational Citizenship Behavior (OCB) dalam Islam. Jurnal Ekonomi dan Sosial, 1(2), 141-148.

Grasiaswaty, N., Juwita, F., \& Setyasih, N. (2014). Adaptasi Alat Ukur Organizational Citizenship Behavior (OCB) dengan Peer Review di Indonesia. 317-325.

Hafidz, S. W. M., Hoesni, S. M., \& Fatimah, O. (2012). The relationship between organizational citizenship behavior and counterproductive work behavior. Asian Social Science, 8(9), 32.

Husain, S. A. (2013). Pengaruh Kecerdasan Emosional (EQ) dan Kecerdasan Spiritual (SQ) 
terhadap kinerja karyawan: Studi kasus pada Kantor Dinas Pendapatan Daerah Kota Malang.

Manfaat Kecerdasan Emosional (EQ). (2020, Januari 16). Manfaat Kecerdasan Emosional (EQ). https://www.gelombangotak.com/Manfaat-Kecerdasan- Emosional(EQ).htm

Masruroh, A. (2014). Konsep Kecerdasan Emosional dalam Perspektif Pendidikan Islam. MUDARRISA: Jurnal Kajian Pendidikan Islam, 6(1), 61-87.

Merrysha Tanu. (2012). Pengaruh Organizational Citizenship Behavior (OCB) Terhadap Kepuasan Kerja Karyawan Studi pada Karyawan Rumah Sakit Pertamina Cirebon [Skripsi]. Sanata Dharma.

Mujib, A., \& Mudzakir, J. (2002). Nuansa-Nuansa Psikologi Islam. PT RajaGrafindo Persada. Mulyatiningsih, E. (2011). Riset Terapan Bidang Pendidikan dan Teknik. UNY Press.

Nur Izzah Maulidina. (2017). Pengaruh Emotional Quotient dan Spiritual Quotient

Terhadap Prestasi Kerja dengan Organizational Citizenship Behavior sebagai Variabel Intervening (Studi pada PT. Bank Syariah Mandiri Malang) [Skripsi]. UIN Maulana Malik Ibrahin Malang.

Rahmawati, T., \& Prasetya, A. (2017). Analisis Faktor-Faktor yang Mempengaruhi Organizational Citizenship Behavior (OCB) Pada Karyawan Tetap dan Karyawan Kontrak (Studi Pada Karyawan Pizza Hut Kota Malang). Jurnal Administrasi Bisnis, 48(1), 97-106.

Sugiyono. (2010). Metode Penelitian Pendidikan (Pendekatan Kuantitatif, Kualitatif, dan RED). Alfabeta.

Sujarweni, V. W. (2019). SPSS Untuk Penelitian. Pustaka Baru Press.

Sumiyarsih, W., Mujiasih, E., \& Ariati, J. (2012). Hubungan Antara Kecerdasan Emosional dengan Organizational Citizenship Behavior (OCB) pada Karyawan CV. Aneka Ilmu Semarang. Jurnal psikologi undip, 11(1), Article 1.

Titisari, P. (2014). Peranan Organizational Citizenship Behavior (OCB) Dalam Meningkatkan Kinerja Karyawan. Mitra Wacana Media.

Toto Tasmara. (2003). Kecerdasan Rohaniyah Transcedentral Intelegensi (III, III) [Computer software]. Gema Insani Pers.

Tri Yuliani. (2018). Hubungan Kecerdasan Spiritual dengan Komitmen Organisasi pada Mahasiswa Pengurus Unit Kegiatan Khusus (UKK) dan Unit Kegiatan Mahasiswa (UKM) di Universitas Islam Negeri Antasari Banjarmasin [Skripsi]. UIN Antasari Banjarmasin.

Zohar, D., \& Marshall, I. (2007). SQ: Kecerdasan Spiritual. Miz

\begin{tabular}{|l|l|l|l|l|}
\hline Submit & Review & Revisi & Diterima & Publis \\
\hline $22-04-20$ & - & - & $25-03-21$ & $30-03-21$ \\
\hline
\end{tabular}

Malahayati, Asmaran AS, dan Shanty Komalasari

Program Studi Psikologi Islam

Fakultas Ushuluddin dan Humaniora

Universitas Islam Negeri Antasari Banjarmasin

Email: Malahayati.MH22@gmail.com 
